\title{
Five-Year Cumulative Incidence of Hypertension in Adult Croatian Population: the CroHort Study
}

\author{
Marijan Erceg', Ana Ivičević-Uhernik ${ }^{1}$, Josipa Kern ${ }^{2}$ and Silvije Vuletić ${ }^{2}$ \\ ${ }^{1}$ Croatian National Institute of Public Health, Zagreb, Croatia \\ 2 University of Zagreb, School of Medicine, »Andrija Štampar« School of Public Health, Zagreb, Croatia
}

\begin{abstract}
A B S T R A C T
The aim of this study was to establish a five-year cumulative incidence of arterial hypertension (hereinafter 5-CIAH) and its dependence on initial prehypertension, body weight, age and gender. "Croatian Adult Health Cohort Study (CroHort) « data collected during 2003 and 2008 for the 1383 subjects aged 18 + with initially normal blood pressure (systolic $<140 \mathrm{mmHg}$ and diastolic $<90 \mathrm{mmHg}$, and not taking medication) was analised. Methods of descriptive statistics, Student's $t$-test, $\chi^{2}$-test and logistic regression were used. The recorded 5-CIAH in male cohort was 36.9\% [32.1 to 41.6] and $33.0 \%$ [30.1 to 36.0] in women and was higher in subjects with initial prehypertension (men 43.3\% [37.5 to 49.0] versus 9.6\% [12.1 to 27.2]; women (42 3\% [38.1 to 46.6] versus 22.3\% [18.5 to 26.1]). The development of arterial hypertension was affected by age $(O R=2.2168)$, initial prehypertension $(O R=2.1987)$ and overweight $(O R=1.9399)$.
\end{abstract}

Key words: CroHort study, hypertension, cumulative incidence, prehypertension, body mass index

\section{Introduction}

Hypertension (hereinafter $\mathrm{AH}$ ) is an important public health challenge due to its high prevalence and strong association with cardiovascular disease and premature death ${ }^{1}$. High blood pressure is the leading cause of death among women, accounting for 19\% of all female deaths, and the second leading cause of death among men (second to smoking) ${ }^{1}$.

The estimated $\mathrm{AH}$ prevalence rate of the global adult population (older than 20 ) was $26.4 \%$ ( 1 billion) in 2000 , and there are projections of growth up to $29.2 \%$ (1.56 billion) by $2025^{1}$. The estimated prevalence of hypertension in developed countries was $37.4 \%$ in men and $37.2 \%$ in women ${ }^{2}$. Prevalence rates in USA (20.3\%) and Canada $(21.4 \%)$ were lower than those recorded in Europe E $^{3,4}$. Several AH prevalence rates were also published in Croatia ${ }^{5-9}$. The Croatian AH rate in 2003 was $44.2 \%^{8}$, closely nearing that of Spain $(45.1 \%)$, lower than the rate reported for Germany (55.3\%), and higher than those for Great Britain (38.8\%), Italy (37.7\%), Sweden (38.4\%) and Greece $(28.4 \%)^{3}$. Limited information is available about the incidence of hypertension because it requires a follow-up of a population for a prolonged period of time ${ }^{10}$. The first $\mathrm{AH}$ incidence rate was estimated in the Fra- mingham cohort follow-up study which gave insight into older age as a risk factor ${ }^{10}$. Several longitudinal cohort studies in USA have shown race differences in the incidence of AH indicating that African Americans' rates were an average of two times higher than Caucasians' ${ }^{11-15}$. In the Atherosclerosis Risk in Communities Study, the 6-year incidence of hypertension was 13.9 percent and 12.6 percent in White men and women, while 24.9 percent and 30.3 percent in African American men and women aged 45-49, respectively ${ }^{12}$.

According to the results of an Italian cohort study, $31.3 \%$ subjects had the initial stage of AH (systolic blood pressure (hereinafter SBP) $>140 \mathrm{mmHg}$ and $<160$ $\mathrm{mmHg}$; diastolic blood pressure (hereinafter DBP) 90-95 $\mathrm{mmHg}$ ), while $14.6 \%$ had the second stage (SBP >160 $\mathrm{mmHg}$; DBP $>95)^{16}$. A Dutch study showed that $7 \%$ of those who had had DBT $<75 \mathrm{mmHg}$ at the beginning developed $\mathrm{AH}$, as did $15 \%$ of those who had initial DBT < $85 \mathrm{mmHg}$ and $30 \%$ with DBP $85-94 \mathrm{mmHg}^{17}$. A French study reported that the incidence of $\mathrm{AH}$ in the working population was $3.0 \%$ in males and $1.34 \%$ in females ${ }^{18}$. Cumulative incidence of $\mathrm{AH}$ in a four-year period in Turkey was documented at a share of $21.4 \%$, while the high- 
est rate was recorded in the $65+$ group $(43.3 \%)^{18}$. In the ATTICA study, the annual incidence of $\mathrm{AH}$ was 2.86 per 100 males and 2.68 per 100 females $^{20}$. Crude AH incidence rate in a Portuguese study was $6.23(5.26-7.20)$ per 100 person years ${ }^{21}$.

Lower rates were recorded in a Indian cohort (2.8/ 1000 in the $25-64$ age group $)^{22}$. In a Taiwanese cohort, the incidence rate was $27 \%$. Age-adjusted incidence rate in a Chinese cohort was $12.75 \%$ in men and $10.4 \%$ in women ${ }^{24}$.

Framingham study showed that the lifetime risk for developing hypertension was $90 \%$ for 55 years old participants $^{25}$.

The literature supporting the linear associations between higher body mass index (hereinafter BMI) and hypertension is well established, and overweight and obesity are major modifiable risk factors ${ }^{26,27}$. Initial higher values of blood pressure or prehypertension have been recognized as another important risk factor for $\mathrm{AH}^{28-30}$. High sodium intake, physical inactivity, heavy alcohol intake, low potassium intake, and a Western-style diet constitute additional risk factors for hypertension ${ }^{31,32}$.

At the moment, no data on $\mathrm{AH}$ incidence in Croatia are available. This paper will, for the first time in Croatia, present a 5-year cumulative incidence of $\mathrm{AH}$ (further 5 -CIAH) in a cohort of initially normotensive subjects.

\section{Materials and Methods}

The paper analyzes the data collected in the Croatian Adult Health Cohort Study (CroHort) project of the Ministry of Science, Education and Sport, No. 108-1080135-0264 , started in 2003 and finished in 2008. The methodology of the CroHort Study, as a tool for monitoring risk factors for cardiovascular diseases, was described in a special paper in this issue ${ }^{33}$. Answers and measurements were collected for 1383 respondents (396 males and 987 females) who fulfilled initial inclusion criteria ( $\mathrm{SBP}<140 \mathrm{mmHg}$ and $\mathrm{DBP}<90 \mathrm{mmHg}$ and not using antihypertension medication statement).

Data was collected by visiting nurses in form of a structured questionnaire, which, among other things, included anthropometric measurements (height, weight and blood pressure), questions on diseases and taking medication, everyday habits and blood pressure measurements. Arterial pressure was measured by a calibrated mercury sphygmomanometer, which uses a standard cuff. Measurements were done in respondents' homes, in a sitting position. Values were read twice in intervals of 20 minutes or longer, and used to compute the average for every respondent.

The criteria for including respondents in the JNC- $7^{32}$ normal blood pressure group were SBP lower than 120 $\mathrm{mmHg}$ and DBP $<90 \mathrm{mmHg}$. The criteria for including respondents in the JNC- $7^{32}$ prehypertension group were SBP $>120 \mathrm{mmHg}$ and SBP $<140 \mathrm{mmHg}$ and/or DBP $>$ $80 \mathrm{mmHg}$ and $<90 \mathrm{mmHg}$. The criteria for including respondents in the JNC- $7^{32}$ group of hypertensive subjects were $\mathrm{SBP} \geq 140 \mathrm{mmHg}$ and/or $\mathrm{DBP} \geq 90 \mathrm{mmHg}$ and/or usage of antihypertensive drugs statement. The criterion for including respondents in the overweight group was $\mathrm{BMI}$ in a range of $25-29.9 \mathrm{~kg} / \mathrm{m}^{2}$ and $\mathrm{BMI} \geq 30 \mathrm{~kg} / \mathrm{m}^{2}$ in the obese group.

The paper shows analytic results expressed in percentages of the 5-year cumulative incidence of $\mathrm{AH}$ (further 5-CIAH), their 95\% confidence intervals (hereinafter $95 \% \mathrm{CI}$ or [ ]), and 5-CIAH annual average. Student t-test, chi-square and logistic regression statistical method were used with $\mathrm{p}=0.05$ as a cut-off value. Data processing was performed using the SPSS statistical package.

\section{Results}

The average age of men $(50.3 \pm 15.5$ year $)$ was significantly higher $(\mathrm{t}=4.7741 ; \mathrm{p}<0.05)$ than of women $(46.0 \pm$ 14.9). In the group of 396 men, $17.4 \%$ belonged to the $18-34$ age group, $61.4 \%$ to the $35-64$ age group and $21.2 \%$ were $65+$. Among 987 females, $25.0 \%$ were aged $18-34,61.4 \%$ were $35-64$ and $13.6 \%$ were $65+$. Age distribution differences between men and women were significant; the former had a distribution that significantly slanted towards the older age group $\left(\chi^{2}=17.5\right.$; d.f. $=2$; $\mathrm{p}<0.05)$.

Cohort crude 5-CIAH was $34.1 \%$ [31.6-36.6] and the average annual $\mathrm{AH}$ incidence rate was $6.8 \%$. There were no significant differences in 5-CIAH between male (36.9\% [32.1-41.6]) and female (33.0\% [30.1-36.0]) groups. Annual average $\mathrm{AH}$ incidence rate was $7.4 \%$ in males and $6.6 \%$ in females.

Age-specific 5-CIAH values grew with age and the highest rates belonged to older age groups in both men and women (Figure 1). In the male 18-34 age group, 5-CIAH was $21.7 \%$ [CI12.0-31.5], and 33.7\% [CI 27.8-39.7]) in the 35-64 age group. Significantly higher 5-CIAH rate was associated with the $65+$ age group $(58.3 \%$ [CI 47.8-68.9]) (Figure 1). In the female 18-34 age group, 5-CIAH was $18.2 \%$ [CI 13.4-23.0], in the 35-64 group it numbered $34.2 \%$ [CI 30.4-37.9], and 55.2\% [CI 46.8-63.6] in the $65+$ age group (Figure 1 ).

In the group of subjects with initially normal blood pressure, 5-CIAH was $19.0 \%$ [CI 12.1-27.2] in males and $26.1 \%$ [CI 18.5-26.1] in females. Significantly higher values of 5-CIAH were recorded in the group of initially prehypertensive men (48.3\% [CI 37.5-49.0] and women (42.3\% [CI 38.1-46.6]) (Figure 2). The impact of initial values of blood pressure on $\mathrm{AH}$ incidence was analyzed in the group of males and females with normal BMI at the end of the follow-up. Among 135 males with normal BMI in the initially normotensive group, $7.1 \%$ (3 in 42) developed hypertension, which was significantly lower than $40.9 \%$ (38 in 93) in the prehypertensive group $\left(\chi^{2}=15.5\right.$; $\mathrm{p}<0.05$ ) (Figure 3). Among 409 women with normal BMI in the group with initially normal blood pressure, $11 \%$ (24 of 218) developed hypertension, which was significantly lower than was the rate of $28.8 \%$ (55 of 191) in the prehypertensive group $\left(\chi^{2}=20.6 ; \mathrm{p}<0.05\right)$ (Figure 3 ). 


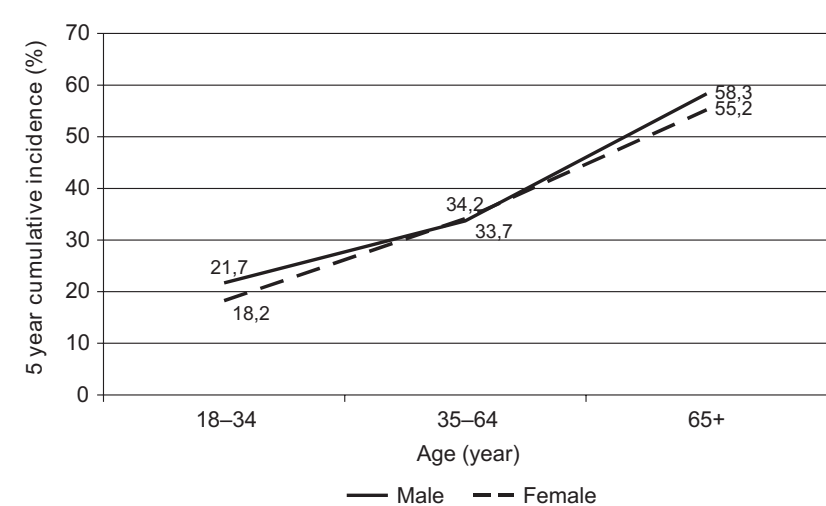

Fig. 1. Distibution of 5-year cumulative incidence of arterial hypertension in cohort of initialy normotensive subjects by age an sex.

In the male group with normal BMI, 5-CIAH was $28.9 \%$ [CI 21.9-36.0] and 23.7\% [CI 20.1-27.4] in the female group. Significantly higher values of 5-CIAH were recorded in the group of obese men than in the group with normal BMI (Figure 4). Values for 95\% CI of 5-CIAH for the overweight population overlapped with those of the normal BMI and obesity groups; consequently no significant differences were noticed (Figure 4). In the female group, significant differences in 5-CIAH were recorded between the normal BMI and overweight/ obese populations (Figure 4).

Unconditional multivariate logistic regression was performed at the end of the follow-up as a criterion variable, while age, sex, body mass index (normal, overweight, obesity) and initial values of blood pressure (normal versus prehypertension) recorded at the beginning of the follow-up served as a predictor. Data for 1378 subjects was analyzed and the predictor of hypertension at the end of the follow-up were prehypertension, BMI and age (Table $1)$. Obesity $(\mathrm{OR}=2.22)$, prehypertension $(\mathrm{OR}=1.97)$, overweight $(\mathrm{OR}=1.59)$ and age $(\mathrm{OR}=1.03)$ of subjects contributed most to the hypertension development. No significant contribution of sex to hypertension development has been recorded.

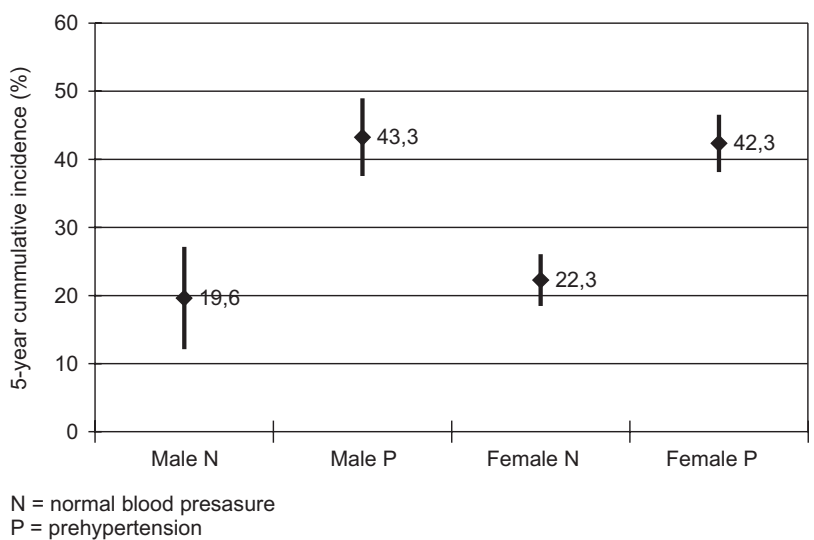

Fig. 2. Arterial hypertension 5-year cumulative incidence in cohort by inital blood pressure status and sex.

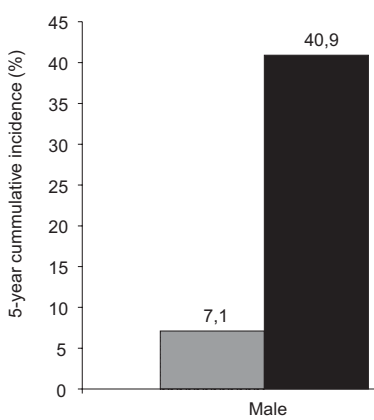

$\square$ Normal blood pressure

- Pre-hypertension

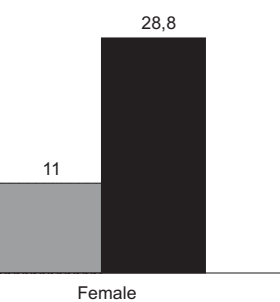

Fig. 3. Arterial hypertension 5-year cumulative incidence in cohort of subjects with normal body mass index by sex and inital blood pressure status (normal blood pressure=systolic $<120$ $\mathrm{mmHg}$ and diastolic $<80 \mathrm{mmHg}$ or prehypertension=systolic pressure $\geq 120 \mathrm{mmHg}$ and $<140 \mathrm{mmHg}$ and/or dyastolic pressure $\geq 80 \mathrm{mmHg}$ and $<90 \mathrm{mmHg}$ ) sex.

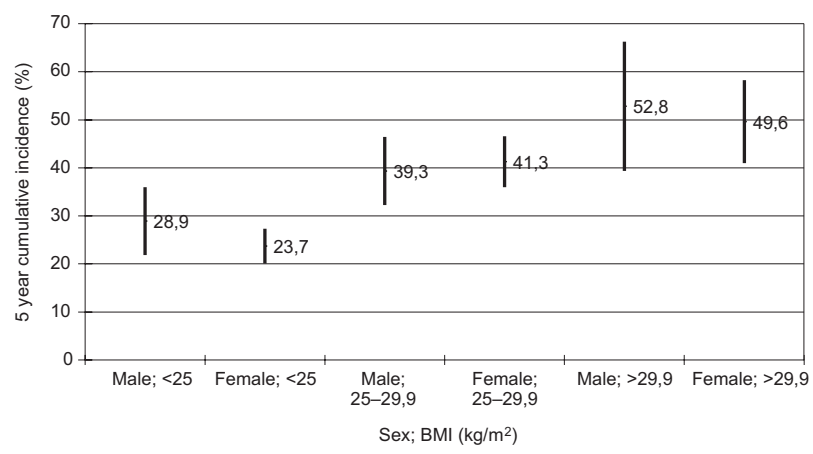

Fig. 4. Arterial hypertension 5-year cumulative incidence in cohort by inital body mass index and sex.

\section{Discussion and Conclusion}

The measured 5-CIAH for the study cohort of subjects was $36.9 \%$ in the group of men and $33.0 \%$ in the group of women, with an average annual incidence of hypertension of $7.4 \%$ for men and $6.6 \%$ for women. The above mentioned values of 5-CIAH were for the first time reported in a study conducted in Croatia.

Due to inconsistent methods of research, rates between different countries cannot easily be compared based on the results published in the literature. Most research uses a method of direct standardization by age and sex, using its population as the standard, and for comparison of incidence trends over time ${ }^{10,11}$. However, due to differences in cohort size, age distribution and different time points in which the research was conducted, the value of the cumulative incidence of hypertension studied cohorts cannot be directly compared with the previously mentioned. The fact, however, remains that they are closer to the values recorded for the Black populations of the USA ${ }^{12}$, Portugal ${ }^{21}$ and Turkey ${ }^{19}$ than the White populations of the United States ${ }^{12,22}$, Grece ${ }^{20}$ or China $^{24}$. 
TABLE 1

RESULTS OF LOGISTIC REGRESSION ANALYSIS

\begin{tabular}{|c|c|c|c|c|c|c|c|}
\hline Term & Odds Ratio & $95 \%$ & C.I. & Coefficient & S. E. & Z-Statistic & $\mathrm{p}$-Value \\
\hline Sex & 1.1372 & 0.8739 & 1.4797 & 0.1285 & 0.1343 & 0.9569 & 0.3386 \\
\hline Age & 1.0316 & 1.0229 & 1.0403 & 0.0311 & 0.0043 & 7.2406 & 0 \\
\hline $\mathrm{BMI}(2 / 1)$ & 1.5851 & 1.2202 & 2.0591 & 0.4606 & 0.1335 & 3.451 & 0.0006 \\
\hline BMI (3/1) & 2.2239 & 1.5603 & 3.1697 & 0.7993 & 0.1808 & 4.4205 & 0 \\
\hline Prehypertension & 1.9652 & 1.5142 & 2.5507 & 0.6756 & 0.133 & 5.0783 & 0 \\
\hline
\end{tabular}

Legend: BMI $1<25 \mathrm{~kg} / \mathrm{m}^{2}<$ BMI $2 \geq 25-29.9 \mathrm{~kg} / \mathrm{m}^{2}<$ BMI $3>29.9 \mathrm{~kg} / \mathrm{m}^{2}$

Although the reported studied cohort 5-CIAH was slightly higher in men than women, this difference was not statistically significant. Earlier studies conducted in the United States found a significant difference in the incidence of hypertension between men and women ${ }^{11}$, whereas in recent studies significantly higher incidence of $\mathrm{AH}$ was established only for men and women of African American descent ${ }^{13}$.

In the monitored cohort, age-specific 5-CIAH increases with age in men and women and is the highest in the oldest age group. In other studies, the highest cumulative incidence rates were also recorded at the oldest age ${ }^{10,25}$. According to the results of the Framingham study, the incidence of hypertension in men grew from $3.3 \%$ at the age of $30-39$ to $6.4 \%$ at $70-79$, while in the group of women it grew from the initial $1.5 \%$ at the age of $30-39$ to $6 \%$ at $70-79^{10}$.

Increase in the $\mathrm{AH}$ incidence with age is attributed to reduced elasticity of artery walls and increasing body mass ${ }^{10}$. A study conducted in a cohort of primitive tribes of Polynesia, which had a physically active lifestyle and lower dietary intake of fats and salt, could not correlate AH with age ${ }^{34}$.

In this research, no age differences in the specific 5 -CIAH were found in relation to sex. According to the results of the Framingham study, men under 50 have higher rates of $\mathrm{AH}$ incidence than women, but women surpass men at an older age ${ }^{10}$.

It is not clear whether there are some unknown environmental factors and differences in behavior or if the reason lies in the fact that men over 50 are the ones who survived, not having died from heart and blood vessel diseases ${ }^{10}$.

A study conducted in a cohort population of China in men detected a higher incidence of $\mathrm{AH}(29.3 \%)$ than in women $(23.4 \%)^{31}$. A study conducted in Greece could not identify differences in annual incidence by $\operatorname{sex}^{20}$.

According to available research, the incidence of $\mathrm{AH}$ increases in initially prehypertensive persons ${ }^{28-30}$. The present study has demonstrated a higher incidence of $\mathrm{AH}$ in a cohort of men and women with initial prehypertension. This difference still remains after the analysis of only those subjects who had normal body weight. In the oldest age groups, no differences in the development of $\mathrm{AH}$ were noticed among normotensive or prehypertensive respondents. In a study conducted in Taiwan, in a cohort of middle-aged and elderly individuals, no differences in the development of the AH relative to the initial values of pressure were identified either ${ }^{28}$.

The results of this study have confirmed a link between obesity measured by BMI with the incidence of $\mathrm{AH}$. The $\mathrm{AH}$ incidence increases with higher body mass index, as in those who are overweight or obese, which is consistent with the results of other studies ${ }^{26,27}$.

This research associates the development of $\mathrm{AH}$ with older age, higher body weight and initial values of blood pressure as independent predictors in a multivariate model, consistently with the results of studies carried out on other cohorts ${ }^{11,13,19,23,24}$.

Proper medication adherence and promotion of healthy nutrition and physical activity to achieve and maintain a normal body weight have the most significant impact on secondary and tertiary prevention and control of $\mathrm{AH}$. Younger prehypertensive population should have at their disposal primary $\mathrm{AH}$ prevention programs that include promotion of physical activity and maintaining weight within the normal range.

\section{Acknowledgements}

This article was prepared as part of the scientific project »Regionalism of cardiovascular behavioural risk factors - model of intervention « (108-1080135-0264) supported by the Ministry of Science, Education and Sports of the Republic of Croatia.

\section{R E F E R E N C E S}

1. LLOYD-JONES D, ADAMS R, CARNETHON M, DE SIMONE G, Circulation, 119(3) (2009):480. - 2. WHO, The World Health Report 2003, (WHO, Geneva, 2003). - 3. WOLF-MAIER K, COOPER RS, KRAMER H,

Hypertension,43 (2004)10. - 4. HE J, MUNTNER P, CHEN J, ROCCELLA EJ, STREIFFER RH, WHELTON PK, Archives of Internal Medicine, 162(2002)1051. — 5. MIMICA M, ČERIĆ B, KULČAR Ž, Lij vjes, 103 
(1981) 533. - 6. TUREK S, RUDAN I, SMOLEJ-NARANČIĆ N, Coll. Antropol, 25(1) (2001)77. - 7. JELAKOVIĆ B, Epidemiologija arterijske hipertenzije u Hrvatskoj: rezultati EH UH studije. U: Prostorna distribucija populacijskih kardiovaskularnih rizika u Hrvatskoj. (Akademija medicinskih znanosti Hrvatske, Zagreb, 2005). - 8. ERCEG M, HRABAK-ŽERJAVIĆ V, UHERNIK A, Acta Med Croatica, 61(2007) 293. — 9. ERCEG M, KERN J, BABIĆ-ERCEG A, IVIČEVIĆ-UHERNIK A, VULETIĆ S, Coll Antropol, 33(Suppl 1) (2009)19. - 10. DANNENBERG AL, GARRISON RJ, KANNEL WB, Am J Public Health, 78(6) (1988) 676. 11. CORNONI-HUNTLEY J, LACROIX AZ, HAVLIK RJ, Arch Intern Med, 149 (1989) 780. — 12. FUCHS FD, CHAMBLESS L E, WHELTON P K, Hypertension, 37(5) (2001)1242 - 13. LEVINE DA, LEWIS CE, WILLIAMS OD, SAFFORD MM, LIU K, CALHOUN DA, KIM Y, JACOBS DR JR, KIEFE CI, Hypertension, 57(1) (2011) 39. - 14. NEMESURE B, WU SY, HENNIS A, Ann Epidemiol, 18(8) (2008) 657. — 15. SUNDSTRÖM J, SULLIVAN L, D'AGOSTINO RB, Hypertension, 42(6) (2003) 1100. 16. SECCARECCIA F, LANTI M, PUDDU PE, J Hypertens Suppl, 6(4) (1988) S602. - 17. BAKX JC, VAN DEN HOOGEN HJ, VAN DEN BOSCH WJ, J Clin Epidemiol, 52(6) (1999) 531. - 18. RADI S, LANG T, LAUWERS-CANCÈS V, CHATELLIER G, J Hum Hypertens, 18(7) (2004) 487. - 19. ARICI M, TURGAN C, ALTUN B, Journal of Hypertension, 28 (2) (2010) 240. - 20. PANAGIOTAKOS DB, CHRYSOHOOU C, PITSA-
VOS C, SKOUMAS J, LENTZAS Y, KATINIOTI A, STEFANADIS C, Atherosclerosis, 206(1) (2009) 314. - 21. CAMÕES M, OLIVEIRA A, PEREIRA M, SEVERO M, LOPES C, J Clin Nutr, 64(12) (2010) 1441. — 22 GOPINATH N, CHADHA SL, SHEKHAWAT S, Indin Heart J, 47(2) (1995) 129. - 23. CHIEN KL, HSU HC, SUNG FC, J Hypertens, 25(7) (2007) 1355. - 24. SUN Z, ZHENG L, DETRANO R, ZHANG X, XU C, LI J, HU D, SUN Y, Ann Fam Med, 8(1) (2010) 19. — 25. VASAN RS, BEISER A, SESHADRI S, JAMA, 287(8) (2002) 1003. - 26. GILLUM RF, MUSSOLINO ME, MADANS JH, International Journal of Obesity, 22 (1998)127. - 27. GELBER RP, GAZIANO JM, MANSON JE, BURING JE, SESSO HD, Am J Hypertens, 20(4) (2007) 370. — 28. LIU LK, PENG LN, CHEN LK, J Atheroscler Thromb, 17(2) (2010) 189. - 29. FERGUSON TS, YOUNGER N, TULLOCH-REID MK, LAWRENCE-WRIGHT MB, FORRESTER TE, COOPER RS, VAN DEN BROECK J, WILKS RJ. West Indian Med J. 59(5) (2010) 486. — 30. ZHENG L, SUN Z, ZHANG X, XU C, LI J, HU D, SUN Y, Eur J Cardiovasc Prev Rehabil, 17(2) (2010) 217. 31. CHOBANIAN A V, BAKRIS G L, BLACK H R, JAMA, 289(19) (2003) 2560. - 32. HE J, MUNTNER P, CHEN J, Archives of Internal Medicin, 162(9) (2002) 1051. — 33. IVIČEVIĆ UHERNIK A, VULETIĆ S, KERN J, DEČKOVIĆ-VUKRES V, MIHEL S; ERCEG M, PRISTAŠ I, Coll Antropol, 36 (Suppl 1) (2012) 3. - 34. PRIOR IAM, EVANS JG, HARVEY HPB, DAVIDSON F, LINDSEY M, N Engl J Med, 279(1968) 515.

\section{Marijan Erceg}

Croatian National Institute of Public Health, Rockefellerova 7, 10000 Zagreb, Croatia

e-mail: marijan.erceg@hzjz.hr

\section{PETOGODIŠNJA KUMULATIVNA INCIDENCIJA ARTERIJSKE HIPERTENZIJE - CroHort STUDIJA}

\section{S A Ž E T A K}

U radu su analizirani podaci za kohortu 1383 ispitanika u dobi 18+ iz Hrvatske kohortne studije kardiovaskularnog zdravlja prikupljeni tijekom intervjua provedenih tijekom 2003. i ponovljenih u 2008. godini. Cilj istraživanja bio je utvrditi kumulativnu petogodišnju incidenciju arterijske hipertenzije (dalje 5-CIAH) i njezinu zavisnost sprema početnim vrijednostima arterijskog tlaka, tjelesnoj masi, dobi i spolu. Istraživanje je provedeno na kohorti ispitanika s početno normalnim arterijskim tlakom (sistolički <140 mmHg i dijastolički <90 mmHg i ne uzima lijekove). Podaci su prikupljani metodom strukturiranog intervjua te antropometrijskim mjerenjima (visina, težina. krvni tlak). Krvni tlak izmjeren je dva puta tijekom istog posjeta i izračunat prosjek za svakog ispitanika. Rezultati su iskazani postotcima 5-CIAH te njihovim 95\% intervalima pouzdanosti (dalje [ ]). Pored metoda deskriptivne statistike korišteni su Studentov t-test, $\chi^{2}$-test, te logistička regresija. Za statističku analizu korišten je statistički paket SPSS. U muškaraca kohorte zabilježena 5-CIAH bila je 36,9 \% [32,1-41,6], a u žena 33.0\% [30.1-36.0]. Ispitanici s početnom predhipertenzijom imali su više vrijednosti 5-CIAH u odnosu na one s početno normalnim tlakom (muškarci 43,3\% [37,5-49,0] naprema 9.6\% [12,1-27,2]; žene $(42,3 \%$ [38,1-46,6] naprema (22,3\% [18,5-26,1]. Razvoju arterijske hipertenzije najviše pridonosi starija dob ispitanika $(\mathrm{OR}=2,2168)$, početna predhipertenzija $(\mathrm{OR}=2,1987)$ te prekomjerna tjelesna masa $(\mathrm{OR}=1,9399)$, dok $\mathrm{za}$ spol to nije utvrđeno. 